\title{
Fine Structure, Physiology and Biochemistry of Arthrospore Germination in Streptomyces antibioticus
}

\author{
By CARLOS HARDISSON, MANUEL-BENJAMIN MANZANAL, \\ JOSÉ-ANTONIO SALAS AND JUAN-EVARISTO SUÁREZ \\ Departamento de Microbiologia, Universidad de Oviedo, Oviedo, Spain
}

(Received 21 July 1977; revised 7 October 1977)

\begin{abstract}
During germination, Streptomyces antibioticus arthrospores passed through three stages: darkening, swelling and germ tube emergence. The first stage, darkening, whose main features were a decrease in absorbance and a loss of refractility, only required exogenous divalent cations $\left(\mathrm{Ca}^{2+}, \mathrm{Mg}^{2+}\right.$ or $\left.\mathrm{Fe}^{2+}\right)$ and energy that can be obtained from the spore reserves. This stage was blocked by agents that inhibit ATP formation but not by antibiotics that inhibit macromolecular synthesis. The second stage, swelling, needed an exogenous carbon source and was not blocked by mitomycin C. In this stage, the spores exhibited the highest cytochrome oxidase and catalase activities and respiratory quotient. The last stage, germ tube emergence, required additional carbon and nitrogen sources. Ammonium compounds were superior to nitrate. Dry weight remained constant during the stages of darkening and swelling, with a rapid increase from the moment of germ tube emergence. Optimum $\mathrm{pH}$ and temperature for germination were 8.0 and $45^{\circ} \mathrm{C}$, respectively. Heat treatment $\left(55^{\circ} \mathrm{C}\right.$ for $\left.10 \mathrm{~min}\right)$ had no effect on germination.

The fine structure of the spore underwent important changes during germination. The wall of the swollen spore became stratified and the inner layer was continuous with the germ tube wall.

Macromolecular synthesis occurred in the sequence RNA, protein and then DNA. Rifampicin, streptomycin and mitomycin $\mathrm{C}$ prevented synthesis when added at the start of incubation. The same effect was obtained if the addition was made during germination, except with mitomycin $\mathrm{C}$ which inhibited DNA, but not RNA and protein synthesis.
\end{abstract}

\section{INTRODUCTION}

We use the term 'germination', as proposed by Cross \& Attwell (1975), to mean the morphogenesis of a resting structure into a vegetative organism. The changes in the fine structure that accompany the germination of spores of Streptomyces have been studied by several workers (Glauert \& Hopwood, 1961; Bradley \& Ritzi, 1968; Dorokhova et al., 1969; Sharples \& Williams, 1976) and all of them have established a similar picture. By contrast, reports on the physiological aspects of spore germination (Attwell \& Cross, 1973; Kalakoutskii \& Pouzharitskaja, 1973; Hirsch \& Ensign, 1975) show contradictory results, mainly with respect to the effect of nutrients and environmental conditions on the process. These discrepancies might be explained by the fact that different species were used for studying the process. There is little information on the biochemical aspects of the process (Kalakoutskii \& Agre, 1976) and very little is known about the sequence and rate of macromolecular synthesis, the effect of inhibitors, the changes in enzymic activities etc. during germination.

This paper deals with the fine structure, physiology and biochemistry of the three stages of the germination process in S. antibioticus: darkening, swelling and germ tube emergence. 


\section{METHODS}

Preparation of spore suspensions. Streptomyces antibioticus ATCC 11891 was grown for 7 to 9 days at $28^{\circ} \mathrm{C}$ in $250 \mathrm{ml}$ flasks containing $75 \mathrm{ml} \mathrm{GAE}$ solid medium [consisting of $\left(\mathrm{g} \mathrm{l}^{-1}\right): \mathrm{K}_{2} \mathrm{HPO}_{4}, 0 \cdot 5 ; \mathrm{MgSO}_{4} .7 \mathrm{H}_{2} \mathrm{O}$, $0.5 ; \mathrm{FeSO}_{4} .7 \mathrm{H}_{2} \mathrm{O}, 0.01$; glucose, 10 ; asparagine, 1 ; yeast extract, $0 \cdot 5$; agar, 20]. Approximately 200 sterilized glass beads ( 3 to $4 \mathrm{~mm}$ diam.) were gently rolled around on the agar surface, then removed and washed with a cold sterile saline solution containing $0.025 \%(\mathrm{w} / \mathrm{v})$ Triton $\mathrm{X}-100$. The resultant suspension was filtered through Whatman no. 1 filter paper to remove fragments of mycelium and washed twice with a cold saline solution by centrifuging at $4{ }^{\circ} \mathrm{C}$ and $12500 \mathrm{~g}$ for $5 \mathrm{~min}$ in a Beckman model $\mathrm{J}-21 \mathrm{~B}$ centrifuge. The final suspension was adjusted to $10^{8}$ spores $\mathrm{ml}^{-1}\left(A_{580}=0.3\right)$. The relation between the absorbance and number of spores was proportional up to $2 \cdot 0 \times 10^{8}$ spores $\mathrm{ml}^{-1}$.

Germination. Freshly harvested spore suspensions $(10 \mathrm{ml})$ were incubated in GAE liquid medium in $100 \mathrm{ml}$ flasks at $35^{\circ} \mathrm{C}$ and 200 rev. $\mathrm{min}^{-1}$ in a Gallenkamp orbital incubator. Germination was determined at different times by two methods. (i) Counting the spores in a Thoma chamber and recognizing, with a phasecontrast microscope, the morphological stages: dormant bright; dark; swollen (diam. at least 1.5 times that of the original spore); and spores with germ tubes (at least as long as the diam. of the swollen spore). (ii) Measuring the decrease in $A_{580}$. A linear relation was found between number of spores and viable units. About $20 \%$ of the spores did not germinate.

Influence of temperature on germination. (i) Thermal death point: samples of dormant and swelling spores $(1 \mathrm{ml})$ in sterile saline solution containing $0.025 \%(\mathrm{w} / \mathrm{v})$ Triton X-100 were heated for $10 \mathrm{~min}$ in a water bath up to $70^{\circ} \mathrm{C}$; viable units were determined in triplicate. (ii) Influence of temperature on germination rate: freshly harvested spores $(10 \mathrm{ml})$ were incubated as described above at temperatures from 23 to $55^{\circ} \mathrm{C}$; at various times samples were withdrawn and the different morphological stages were counted in a Thoma chamber as described above.

Influence of $\mathrm{pH}$ on germination. To determine the effect of $\mathrm{pH}$ on germination, the components of GAE medium were dissolved in the following solutions $(0.1 \mathrm{M})$ (Gomori, 1955): $\mathrm{HCl} / \mathrm{KCl}$ solution, pH 1 to 2 ; citrate buffer, $\mathrm{pH} 3$ to $6 ; \mathrm{K}_{2} \mathrm{HPO}_{4} / \mathrm{KH}_{2} \mathrm{PO}_{4}$ buffer, pH 6 to 8 ; Tris/HCl buffer, pH 8 to $9 ;$ and $\mathrm{Na}_{2} \mathrm{CO}_{3} /$ $\mathrm{NaHCO}_{3}$ buffer, $\mathrm{pH} 10$.

Influence of cations, nutrients and inhibitors on germination. The effects of the divalent cations $\mathrm{Ca}^{2+}, \mathrm{Mg}^{2+}$ and $\mathrm{Fe}^{2+}[0.001 \%(\mathrm{w} / \mathrm{v})$ in distilled water] on spore germination were assayed. Fourteen carbon sources and seventeen nitrogen sources, at final concentrations of $1 \%$ and $0.2 \%(\mathrm{w} / \mathrm{v})$, respectively, were tested using the mineral salts of GAE medium as a basal medium. As a result of these experiments, a defined medium was developed which contained $\left(\mathrm{g} \mathrm{l}^{-1}\right)$ : glucose, $10 ;\left(\mathrm{NH}_{4}\right)_{2} \mathrm{SO}_{4}, 2 ; \mathrm{KH}_{2} \mathrm{PO}_{4}, 0 \cdot 5 ; \mathrm{MgSO}_{4} .7 \mathrm{H}_{2} \mathrm{O}$, $0.5 ; \mathrm{FeSO}_{4} .7 \mathrm{H}_{2} \mathrm{O}, 0.01$. Inhibitors were added to $\mathrm{GAE}$ medium at the start of incubation; germination was considered to be inhibited if germ tubes were absent after $6 \mathrm{~h}$ incubation. GAE medium alone was employed as a control.

Oxygen determinations during germination. All the oxygen determinations were carried out at $35^{\circ} \mathrm{C}$ in an YSI model 53 Biological Oxygen Monitor equipped with a Clark oxygen electrode (Yellow Springs Instrument Co., Yellow Springs, Ohio, U.S.A.). Spore suspensions of $2.0 \times 10^{8}$ spores $\mathrm{ml}^{-1}$ in 5 mm-phosphate buffer $\mathrm{pH} 7.0$ were incubated in the reaction vessel for $3 \mathrm{~min}$ before the reaction was initiated by adding the respective substrates. The suspensions were mixed by magnetic agitation.

Respiratory quotient. The substrate used was $20 \mathrm{~mm}$-glucose. The data obtained were corrected by subtracting endogenous values.

Cytochrome oxidase activity. The substrates used were $10 \mathrm{~mm}$-sodium ascorbate and $2.5 \mathrm{~mm}-N, N, N^{\prime}$, $N^{\prime}$-tetramethyl-p-phenylenediamine (TMPD). Suitable controls were included to ensure that ascorbate oxidation did not occur with spores prior to the addition of TMPD in the assay and that no enzymic autooxidation reaction occurred without spores (Jurtshuk, Marcucci \& McQuitty, 1975).

Catalase activity. Catalase activity was determined according to Rorth \& Jensen (1967) with $1 \mathrm{mM}^{-\mathrm{H}_{2} \mathrm{O}_{2}}$ as substrate. The observed catalase activity was corrected by subtracting the rate of oxygen release from $\mathrm{H}_{2} \mathrm{O}_{2}$ in the absence of spores and by adding the endogenous rate of oxygen consumption by spores in the absence of $\mathrm{H}_{2} \mathrm{O}_{2}$ (Cole \& Rittenberg, 1971). A unit of catalase activity was defined as the amount of enzyme which decomposed $1.0 \mu \mathrm{mol} \mathrm{H}_{2} \mathrm{O}_{2} \min ^{-1}$ at $35^{\circ} \mathrm{C}$, under the specified conditions for the assay.

Rate of synthesis and total amount of macromolecules. The rates of synthesis of RNA, protein and DNA were determined by measuring the incorporation of $\left[{ }^{3} \mathrm{H}\right]$ uridine, $\left[{ }^{3} \mathrm{H}\right]$ leucine and $\left[{ }^{3} \mathrm{H}\right]$ thymine, respectively, (each at $1 \mu \mathrm{Ci} \mathrm{ml}{ }^{-1}$ ) into the macromolecules during germination in $\mathrm{GAE}$ medium containing the corresponding non-radioactive compound (at $25 \mu \mathrm{g} \mathrm{ml}^{-1}, 10 \mu \mathrm{g} \mathrm{ml}^{-1}$ and $5 \mu \mathrm{g} \mathrm{ml}^{-1}$, respectively). In the case of [ ${ }^{3} \mathrm{H}$ ]thymine incorporation, it was necessary to add $500 \mu \mathrm{g}$ 2-deoxyadenosine $\mathrm{ml}^{-1}$ to the culture (Lammi \& Vary, 1972). At fixed times, $1 \mathrm{ml}$ samples were withdrawn and the incorporation of label was stopped immediately by adding them to $1 \mathrm{ml} 5 \mathrm{~mm}$-sodium azide containing non-labelled compound $\left(100 \mu \mathrm{g} \mathrm{ml}^{-1}\right)$. The results were 
the same when $5 \%(\mathrm{w} / \mathrm{v})$ trichloroacetic acid was used. After $30 \mathrm{~min}$ at $0{ }^{\circ} \mathrm{C}$, samples were filtered through Whatman GF/C glass fibre filters and washed with $75 \mathrm{ml}$ distilled water. The filters were dried and then counted in $2 \mathrm{ml}$ of a standard scintillation fluid, using a liquid scintillation spectrophotometer. The effect of antibiotics on macromolecular synthesis was determined by pulse-labelling. At intervals the antibiotic was added to a germinating culture and then $1 \mathrm{ml}$ samples were transferred to tubes containing $1 \mu \mathrm{Ci}$ of the radioactive compound for $3 \mathrm{~min}$. The reaction was stopped and all subsequent steps were as described above.

The total amounts of macromolecules present during germination were determined using $60 \mathrm{ml}$ of suspension containing $10^{8}$ spores $\mathrm{ml}^{-1}$ in GAE medium. Samples were taken every $30 \mathrm{~min}$ for $3 \mathrm{~h}$. These were centrifuged and the pellet was washed twice with saline solution in a refrigerated centrifuge (Beckman model $\mathrm{J}-21 \mathrm{~B}$ ) at $12500 \mathrm{~g}$ and $4{ }^{\circ} \mathrm{C}$ for $10 \mathrm{~min}$. The pellet was suspended in $14 \mathrm{ml} 0.1 \mathrm{M}$-Tris/ $\mathrm{HCl}$ buffer pH 7.3 containing $1.25 \mathrm{~mm}$-EDTA to inactivate nucleases, combined with $10 \mathrm{~g}$ glass beads $(0 \cdot 1 \mathrm{~mm}$ diam.) and disrupted in a Braun model MSK mechanical homogenizer (Braun, Melsungen, West Germany), cooled with solid carbon dioxide, for $3 \mathrm{~min}$ at $4000 \mathrm{rev}$. $\mathrm{min}^{-1}$. The crude extract was made $0.25 \mathrm{M}$ with respect to $\mathrm{HClO}_{4}$ and left for $30 \mathrm{~min}$ in an ice bath. This suspension was centrifuged at $6000 \mathrm{~g}$ for $10 \mathrm{~min}$ and the pellet was extracted with $0.5 \mathrm{M}-\mathrm{HClO}_{4}$ at $70^{\circ} \mathrm{C}$ for $20 \mathrm{~min}$ with occasional shaking and then centrifuged. The treatment was repeated three times and the combined supernatants were used for determinations of DNA and RNA. DNA was determined by the diphenylamine assay (Burton, 1956) with deoxyribose as standard. RNA was assayed by the orcinol assay (Schneider, 1957) with ribose as standard. For protein measurement, the remaining pellet was boiled for $15 \mathrm{~min}$ in $1 \mathrm{M}-\mathrm{NaOH}$ and the supernatant fluid was assayed by method of Lowry $e t$ al. (1951).

Electron microscopy. At different times during germination, $10 \mathrm{ml}$ samples were taken, prefixed with $1 \mathrm{ml} 1 \%(\mathrm{w} / \mathrm{v}) \mathrm{OsO}_{4}$ and centrifuged at $6000 \mathrm{~g}$ for $5 \mathrm{~min}$. Fixation, embedding and sectioning were carried out as previously described (Hardisson \& Manzanal, 1976). Sections were poststained by floating on uranyl acetate. Pictures were taken with a Philips EM-300 electron microscope operating at $80 \mathrm{kV}$.

\section{RESULTS}

\section{Morphological and absorbance changes during germination}

Recently harvested spores of Streptomyces antibioticus were phase bright; after about 60 min incubation, spores became completely phase dark. The loss of brightness of the spores was accompanied by about a $20 \%$ fall in the absorbance of the suspension. The spores then swelled reaching a maximum after about 120 min incubation. Finally, the germ tubes emerged after about 140 to $160 \mathrm{~min}$ incubation and the absorbance increased linearly (Fig. 1). Although germination in these conditions was not a completely synchronous process, there was a marked predominance of one stage over the others during the process (Table 1).

\section{Effect of temperature on germination rate}

The germination rate for mycelial organisms like Streptomyces can be determined by measuring the percentage of germ tubes formed at fixed times. At all temperatures tested, the percentage of germ tube formation increased linearly with the incubation time (Fig. $2 a$ ). The slopes of the straight lines obtained correspond to the respective rates. We chose the minimum time required for $50 \%$ of the spores to form germ tubes as a measure of the germination rate, and plotted these values as a function of temperature (Fig. $2 b$ ). The optimum temperature range was between 35 and $47.5^{\circ} \mathrm{C}$ and the germination rate was maximum at $45^{\circ} \mathrm{C}$.

\section{Thermal death point and staining by basic dyes}

The viability of dormant spores was not affected by incubation at $60{ }^{\circ} \mathrm{C}$ for $10 \mathrm{~min}$, but at $65{ }^{\circ} \mathrm{C}, 99.99 \%$ of the spores died. Dormant spores did not take up basic dyes such as methylene blue; dark and swollen spores were stained immediately by the dye and died at $60{ }^{\circ} \mathrm{C}$.

\section{Effect of $p H$}

The spores germinated within the $\mathrm{pH}$ range $6 \cdot 0$ to $9 \cdot 5$. The optimum was between $7 \cdot 5$ and 9.0 , but the germination rate was maximum at $\mathrm{pH} 8.0$. The composition of the buffer 


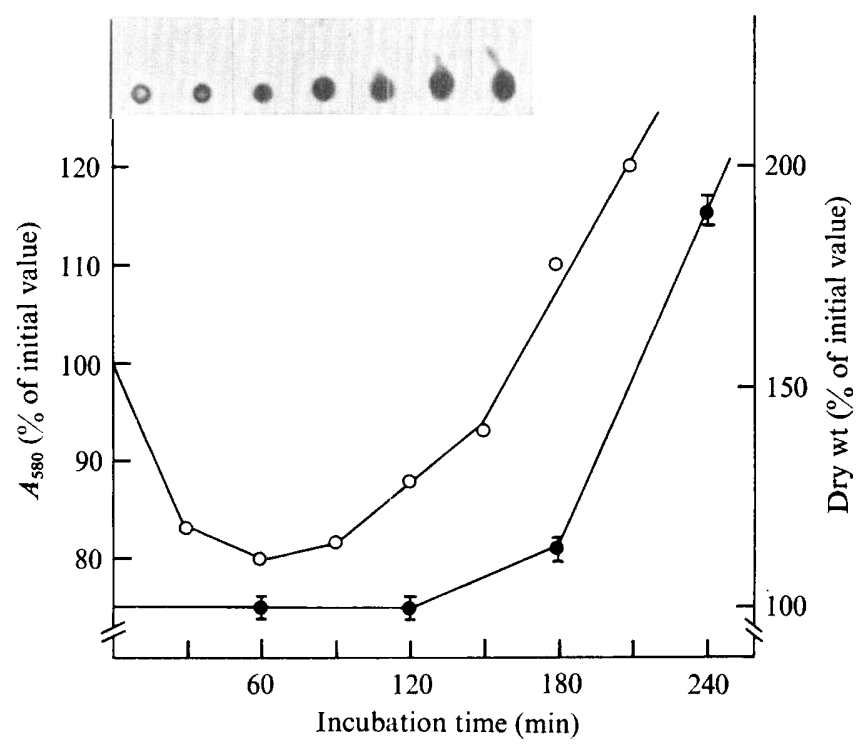

Fig. 1. Morphological, absorbance $(O)$ and dry weight $(\bullet)$ changes during germination of Streptomyces antibioticus spores in GAE liquid medium. The sequence of photographs illustrates the appearance of typical germinating spores at the times indicated. Dry weights were determined, using samples of about $3 \times 10^{\circ}$ spores, by direct weighing of cells after drying to constant weight. Each point was determined in quintuplicate.

\section{Table 1. Percentage of different morphological stages during germination of Streptomyces antibioticus spores}

Spore suspensions $(10 \mathrm{ml})$ were incubated in GAE liquid medium in $100 \mathrm{ml}$ flasks at $35^{\circ} \mathrm{C}$ and $200 \mathrm{rev} \cdot \mathrm{min}^{-1}$. Data were calculated from observations of 200 spores and are the result of several independent experiments.

Incubation time (h)

$\begin{array}{lccccc}\text { Spores } & 0 & 1 & 2 & 3 & 4 \\ \text { Dormant } & 100 & 15-25 & 15-25 & 15-25 & 15-25 \\ \text { Dark } & - & 60-70 & 20-30 & - & - \\ \text { Swelling* } & - & 10-20 & 50-60 & 30-35 & 10-20 \\ \text { With germ tubes } \dagger & - & - & - & 35-55 & 60-75\end{array}$

* Diameter at least 1.5 times the original spore diameter.

$\dagger$ Germ tube at least as long as the diameter of the swollen spore.

did not seem to have any influence on the germination rate, because similar results were obtained at $\mathrm{pH} 6.0$ in citrate or phosphate buffer and at $\mathrm{pH} 8.0$ in phosphate or Tris $/ \mathrm{HCl}$ buffer.

\section{Effect of nutrients and inhibitors on germination}

Spores did not germinate in distilled water; the addition of phosphate had no effect. The initial stage, i.e. darkening, depended only on the presence of divalent metal ions; the same results were obtained in $0.001 \%(\mathrm{w} / \mathrm{v}) \mathrm{MgSO}_{4}, \mathrm{FeSO}_{4}$ or $\mathrm{CaCl}_{2}$. Inhibitors of respiration [sodium azide, potassium cyanide or EDTA (each at $1.25 \mathrm{~mm}$ ), atebrin $(0.1 \mathrm{~mm})$ and 2,4-dinitrophenol $(0.5 \mathrm{~mm})]$ completely inhibited this stage. This indicates that darkening is an energy-requiring process and the respiratory metabolism of endogenous reserves provides the energy to support it. Macromolecular synthesis was not needed for this stage since darkening occurred in the presence of streptomycin, rifampicin or mitomycin $\mathrm{C}$ (each at $5 \mu \mathrm{g} \mathrm{ml}^{-1}$ ). Spore swelling was dependent upon an external supply of assimilable carbon compounds [Table 2; salts and salts + glucose], but was not stimulated by nitrogen [Table 2; 

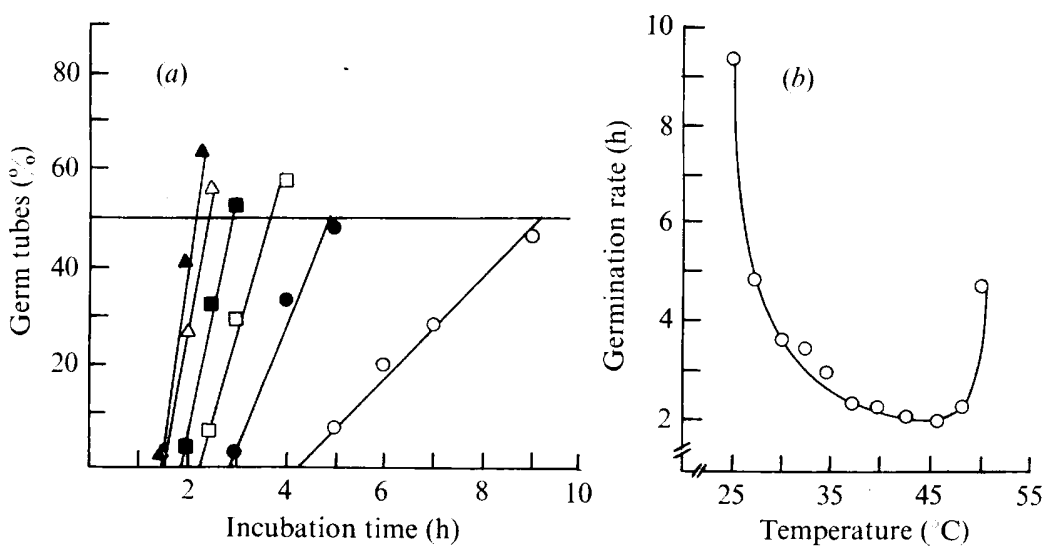

Fig. 2. Effect of temperature on germ tube formation in Streptomyces antibioticus. (a) Percentage of germ tubes formed at $25^{\circ} \mathrm{C}(\bigcirc), 30^{\circ} \mathrm{C}(\square), 35^{\circ} \mathrm{C}(\boldsymbol{\nabla}), 40^{\circ} \mathrm{C}(\triangle), 45^{\circ} \mathrm{C}(\Delta)$ and $50{ }^{\circ} \mathrm{C}(\boldsymbol{0})$. (b) Minimum time required for $50 \%$ of the spores to form germ tubes, using data from $(a)$. Data corresponding to $27 \cdot 5,32 \cdot 5,37 \cdot 5,42 \cdot 5$ and $47 \cdot 5{ }^{\circ} \mathrm{C}$ are not shown in $(a)$.

Table 2. Effect of nutrients on swelling and germ tube formation in spores of Streptomyces antibioticus

Observations were made after $6 \mathrm{~h}$ incubation; the results presented are the average of three independent experiments.

Nutrient

Distilled water

Phosphate buffer

Salts (of GAE medium)

Salts $+\left(\mathrm{NH}_{4}\right)_{2} \mathrm{SO}_{4}(0 \cdot 2 \%)$

Salts + glucose $(1 \%)$

Salts + glucose $(1 \%)+\mathrm{NaNO}_{3}(0.2 \%)$

Salts + glucose $(1 \%)+\left(\mathrm{NH}_{4}\right)_{2} \mathrm{SO}_{4}(0 \cdot 2 \%)$

GAE medium

\begin{tabular}{cccc}
\multicolumn{4}{c}{ Spores $(\%)$} \\
$\begin{array}{c}\text { Dormant } \\
100\end{array}$ & $\begin{array}{c}\text { With germ } \\
\text { tubes }\end{array}$ \\
100 & - & - & - \\
20 & 68 & - & - \\
16 & 72 & 12 & - \\
23 & 19 & 58 & - \\
17 & 47 & 26 & 10 \\
15 & 5 Swelling \\
\multicolumn{4}{c}{ Mycelium } \\
\end{tabular}

\section{Table 3. Effect of inhibitors on germination of Streptomyces antibioticus spores}

The inhibitors were added at the start of incubation. Morphological features are indicated by the following symbols: 1 , darkening; 2 , swelling; 3 , germ tubes; 4 , mycelium.

GAE medium + inhibitor $\left(\mu \mathrm{g} \mathrm{ml}^{-1}\right)$

\begin{tabular}{|c|c|c|c|c|c|c|c|c|c|c|c|c|c|c|c|c|}
\hline \multirow{2}{*}{$\begin{array}{l}\text { Incubation } \\
\text { time (h) }\end{array}$} & \multirow{2}{*}{$\begin{array}{c}\text { GAE } \\
\text { (codium }\end{array}$} & \multicolumn{3}{|c|}{ Streptomycin } & \multicolumn{3}{|c|}{ Rifampicin } & \multicolumn{3}{|c|}{ Actinomycin D } & \multicolumn{3}{|c|}{ Mitomycin C } & \multicolumn{3}{|c|}{ Chloramphenicol } \\
\hline & & 1 & 5 & 10 & 1 & 5 & 10 & 1 & 5 & 10 & 1 & 5 & 10 & 10 & 50 & 100 \\
\hline $\begin{array}{r}6 \\
24\end{array}$ & $\begin{array}{l}3 \\
4\end{array}$ & $\begin{array}{l}1 \\
3\end{array}$ & $\begin{array}{l}1 \\
2\end{array}$ & $\begin{array}{l}1 \\
2\end{array}$ & $\begin{array}{l}3 \\
4\end{array}$ & $\begin{array}{l}1 \\
2\end{array}$ & $\begin{array}{l}1 \\
2\end{array}$ & $\begin{array}{l}1 \\
3\end{array}$ & $\begin{array}{l}1 \\
1\end{array}$ & $\begin{array}{l}1 \\
1\end{array}$ & 2 & $\begin{array}{l}2 \\
2\end{array}$ & $\begin{array}{l}2 \\
2\end{array}$ & $\begin{array}{l}3 \\
4\end{array}$ & $\begin{array}{l}1 \\
1\end{array}$ & $\begin{array}{l}1 \\
1\end{array}$ \\
\hline
\end{tabular}

salts and salts $+\left(\mathrm{NH}_{4}\right)_{2} \mathrm{SO}_{4}$ ]; this stage was independent of DNA synthesis because mitomycin $\mathrm{C}$ did not affect swelling (Table 3). Germ tube formation was dependent upon an external supply of carbon and nitrogen compounds (Table 2). Ammonium compounds were superior to nitrate [Table 2; salts + glucose $+\left(\mathrm{NH}_{4}\right)_{2} \mathrm{SO}_{4}$ and salts + glucose $+\mathrm{NaNO}_{3}$ ] Seventeen individual L-amino acids, at $0.2 \%(\mathrm{w} / \mathrm{v})$ final concentration, were tested to find the best nitrogen source. Five of them (histidine, isoleucine, glycine, proline and alanine) gave roughly the same results as $\left(\mathrm{NH}_{4}\right)_{2} \mathrm{SO}_{4}$, although only alanine $(1 \%$, w/v) fulfilled the 


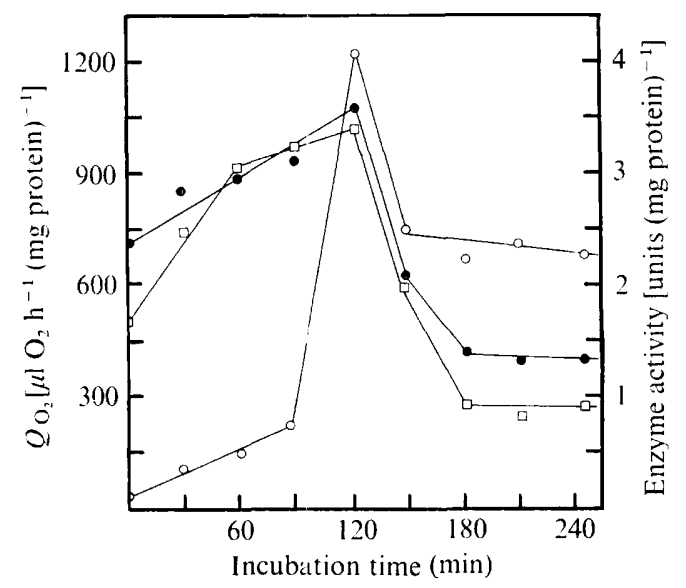

Fig. 3. Respiratory quotient, cytochrome oxidase and catalase activities during germination of Streptomyces antibioticus spores. The activities were measured with a Clark oxygen electrode at $35^{\circ} \mathrm{C}$. The reaction mixture contained $5.0 \mathrm{~mm}$-phosphate buffer $\mathrm{pH} 7.0$ and substrate in a final volume of $5 \mathrm{ml}$. The respiratory quotient $Q_{\mathrm{O}_{2}}(O)$ was measured using $2 \mathrm{~mm}$-glucose as substrate; cytochrome oxidase activity (๑) was measured using $10 \mathrm{~mm}$-ascorbate and $2.5 \mathrm{mM}-N, N, N^{\prime}, N^{\prime}$-tetramethyl-p-phenylenediamine; catalase activity $(\square)$ was determined by measuring the breakdown of $1 \mathrm{mM}-\mathrm{H}_{2} \mathrm{O}_{2}$ and the consequent release of oxygen. All results were corrected by subtracting the endogenous activities without substrate.


Fig. 4. Kinetics of RNA (O), DNA ( $\square$ ) and protein (๑) synthesis during germination of Streptomyces antibioticus spores. (a) Measured by incorporation of exogenous labelled precursors. Spores were incubated in GAE medium containing, respectively, $\left[{ }^{3} \mathrm{H}\right]$ uridine, $\left[{ }^{3} \mathrm{H}\right]$ thymine or $\left[{ }^{3} \mathrm{H}\right]$ leucine from the start of incubation. At the indicated times, $1 \mathrm{ml}$ samples were taken and analysed as outlined in Methods. (b) Measured by chemical methods. At the indicated times, samples of $10^{10}$ spores were collected by centrifugation, washed twice in saline solution and suspended in cold $0.1 \mathrm{M}$-Tris/HCl pH 7.3 containing $1.25 \mathrm{~mm}$-EDTA. RNA, DNA and protein were extracted and estimated as described in Methods.

requirements for carbon and nitrogen necessary for germ tube formation. The other amino acids tested (asparagine, glutamine, arginine, glutamic acid, aspartic acid, tryptophan, tyrosine, phenylalanine, leucine, cysteine, cystine and serine) did not allow the formation of germ tubes. Fourteen carbon compounds, at $1 \%(\mathrm{w} / \mathrm{v})$ final concentration, were also tested. Five of them (galactose, sucrose, maltose, cellobiose and starch) gave the same results as glucose (50 to $60 \%$ germ tube formation after $6 \mathrm{~h}$ incubation). The addition to 

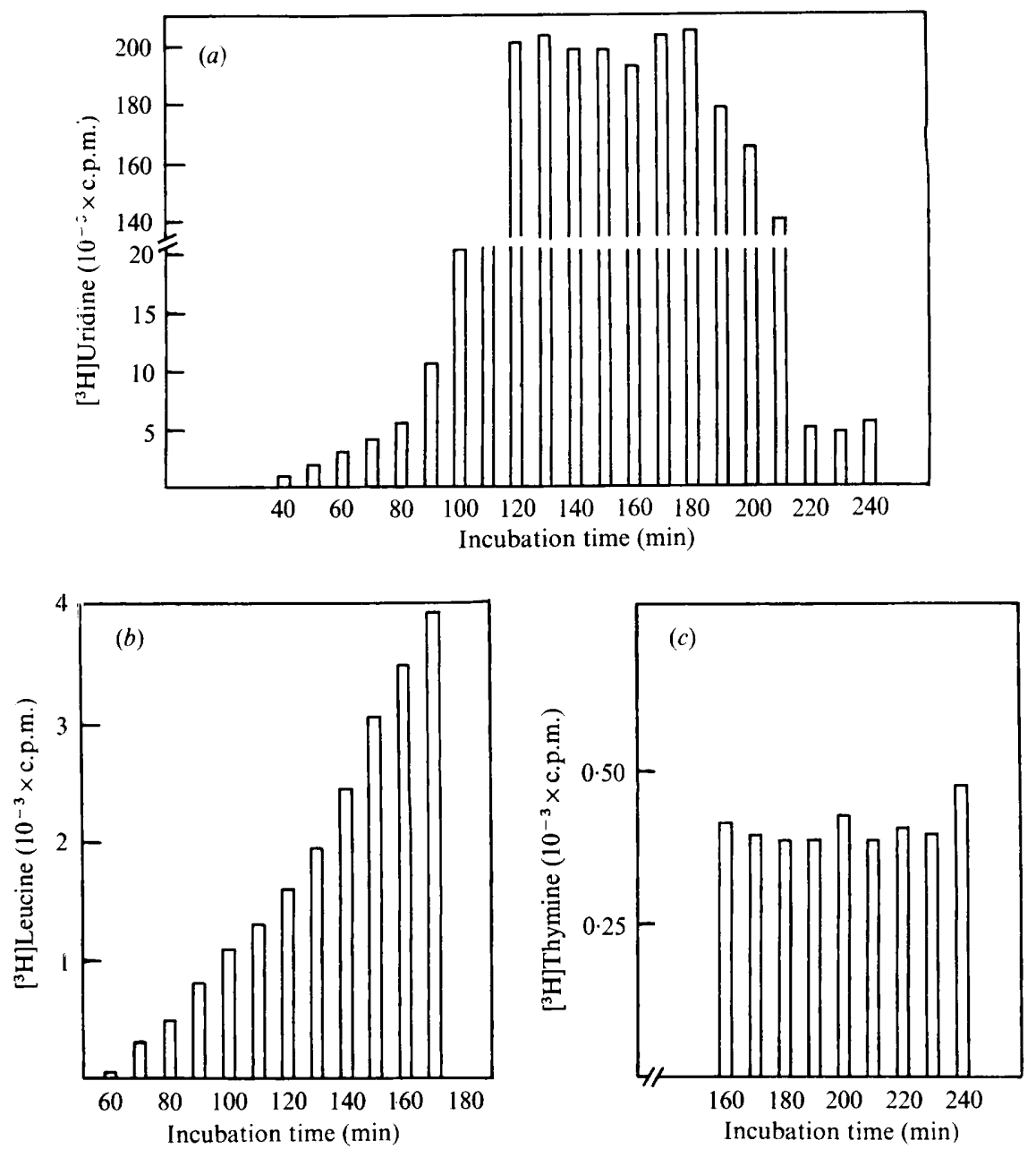

Fig. 5. Pulse-labelling patterns for RNA $(a)$, protein $(b)$ and DNA $(c)$ synthesis during germination of Streptomyces antibioticus spores. Samples $(1 \mathrm{ml})$ were taken at 10 min intervals from the start of germination, incubated with labelled precursors for $3 \mathrm{~min}$ and assayed for radioactivity as described in Methods. Where no bars are shown, no radioactivity was detected.

the defined medium of growth factors (adenosine and p-aminobenzoic acid, each at $50 \mu \mathrm{g}$ $\mathrm{ml}^{-1}$, either alone or together) had no effect on germ tube formation. In GAE medium, much mycelium was obtained after $4 \mathrm{~h}$ incubation.

\section{Respiratory quotient, cytochrome oxidase and catalase activities during germination}

Maximum activities were reached after $120 \mathrm{~min}$ incubation (Fig. 3), the time corresponding to the maximum number of swollen spores (Table 1). Germ tube emergence was accompanied by a decrease in all these activities, which later reached constant values.

\section{Macromolecular synthesis during germination}

The synthesis of macromolecules during germination was determined by measuring the incorporation of exogenous labelled precursors (Fig. $4 a$ ) and by chemical methods (Fig. $4 b$ ). The sequence of macromolecular synthesis during germination was RNA, protein and finally DNA. The incorporation of $\left[{ }^{3} \mathrm{H}\right]$ uridine into RNA began after 40 min incubation; it was initially slow but increased considerably after about 100 to $120 \mathrm{~min}$ incubation. The 

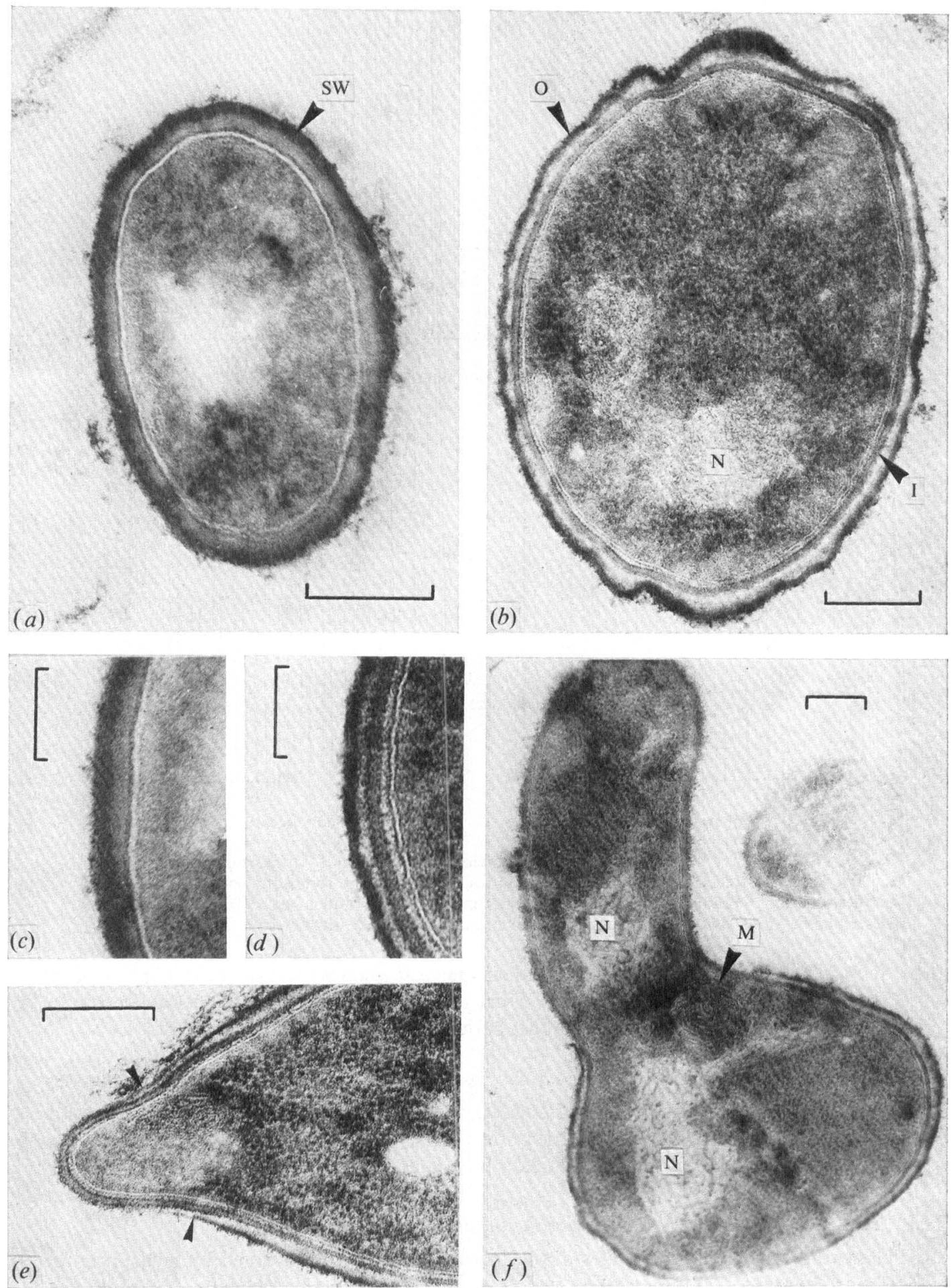
incorporation of $\left[{ }^{3} \mathrm{H}\right]$ leucine into protein began after $60 \mathrm{~min}$ incubation; again the rate of incorporation was initially slow, increasing after $120 \mathrm{~min}$ incubation. The incorporation of $\left[{ }^{3} \mathrm{H}\right]$ thymine into DNA began after 150 to $160 \mathrm{~min}$ incubation, i.e. at the time of outgrowth.

The rates of RNA, protein and DNA synthesis during germination were also determined by pulse-labelling of samples taken at $10 \mathrm{~min}$ intervals from the start of germination. The pattern of $\left[{ }^{3} \mathrm{H}\right]$ uridine incorporation (Fig. $5 a$ ) showed three stages. During the first, the rate of incorporation was slow and increased slowly up to $80 \mathrm{~min}$. The rate then increased rapidly and by $120 \mathrm{~min}$ was about 100 times the initial incorporation rate and remained constant for up to $180 \mathrm{~min}$; this period corresponded to the transition from swollen spore to germ tube emergence. Later, the incorporation rate decreased and soon reached very low values. These observations can be explained by the turnover of cellular RNA. The pattern of $\left[{ }^{3} \mathrm{H}\right]$ leucine incorporation (Fig. $5 b$ ) showed two different rates of increase of incorporation rate: the slower one occurred from 60 to $120 \mathrm{~min}$; after $120 \mathrm{~min}$ the rate of increase of incorporation rate increased by a factor of two and thereafter remained at this rate. $\left[{ }^{3} \mathrm{H}\right]$ Thymine incorporation (Fig. $5 c$ ) did not start until after $160 \mathrm{~min}$ incubation and from this moment the incorporation rate was constant.

\section{Effect of inhibitors on macromolecular synthesis during germination}

The addition of antibiotics that inhibit synthesis of RNA (rifampicin, $5 \mu \mathrm{g} \mathrm{ml}^{-1}$ ), protein (streptomycin, $5 \mu \mathrm{g} \mathrm{ml}^{-1}$ ) or DNA (mitomycin $\mathrm{C}, 5 \mu \mathrm{g} \mathrm{ml}^{-1}$ ) to dormant spores at zero time, completely blocked the incorporation of labelled precursors into macromolecules. When added at different times during the germination process, rifampicin and streptomycin soon inhibited the incorporation of labelled precursors into the three macromolecules, as measured by pulse-labelling. Mitomycin $\mathrm{C}$ did not affect the incorporation of $\left[{ }^{3} \mathrm{H}\right]$ uridine when added after $60 \mathrm{~min}$ incubation, nor that of $\left[{ }^{3} \mathrm{H}\right]$ leucine when added after 60 or 120 min. In contrast, the incorporation of $\left[{ }^{3} \mathrm{H}\right]$ thymine into DNA was completely inhibited 20 min after the addition of mitomycin $C$, when added after 140 or 160 min incubation.

\section{Fine structure of germination}

The changes in fine structure that accompanied germination are shown in Fig. 6. Dormant spores had a mean diameter of $0.5 \mu \mathrm{m}$. Electron micrographs (Fig. $6 \mathrm{a}$ ) show that the penetration by the fixatives at this stage was poor, and no cytoplasmic structures, nuclear material or ribosomes were seen. Their walls were 40 to $50 \mathrm{~nm}$ thick. Swollen spores had a diameter of 0.8 to $0.9 \mu \mathrm{m}$ and cytoplasmic structures (plasma membrane, mesosomes, nuclear material and ribosomes) were clearly visible (Fig. $6 b$ ). This different appearance was at least partially due to the increasing permeability of the wall which allowed the penetration of fixatives. The transition from the dormant to the swollen stage was accompanied by changes in the spore wall (Fig. $6 c, d$ ). In the swollen spore wall, outer and inner layers, each $13 \mathrm{~nm}$ thick, could be clearly distinguished. The inner spore wall extended and then pushed out through the broken outer layer to form the germ tube wall (Fig. $6 e, f$ ).

Fig. 6. Ultrastructure of spore germination in Streptomyces antibioticus. (a) Section of a dormant spore. No structures can be seen within the cytoplasm. Bar marker represents $200 \mathrm{~nm}$. (b) Longitudinal section of a swollen spore showing the cytoplasmic membrane, nuclear material, abundant ribosomes and inner and outer layers in the cell wall. Bar marker represents $200 \mathrm{~nm} .(c),(d)$ Enlarged detail of the spore wall in a dormant spore and in a swollen spore. Note the outer and inner layer in the cell wall of the swollen spore. Bar markers represent $100 \mathrm{~nm}$. (e) Section of a germinating spore at an early stage of germ tube emergence. Note the continuity of the germ tube cell wall with the inner layer of the spore cell wall. The outer layer broke at the points indicated by arrows. Bar marker represents $200 \mathrm{~nm}$. $(f)$ Longitudinal section of a spore with a well developed germ tube. Bar marker represents $200 \mathrm{~nm}$. SW, Spore wall; O, outer spore wall; I, inner spore wall; $\mathrm{N}$, nuclear material; $\mathrm{M}$, mesosome. 
Figure $6(f)$ shows a spore with a well developed germ tube with two nuclear regions, one of which has moved out to the germ tube.

\section{DISCUSSION}

The germination process in $S$. antibioticus may be divided into three different sequential morphological stages: darkening, swelling and germ tube emergence. The darkening of dormant spores, characterized by a loss of refractility and a decrease in absorption, requires only divalent metal ions $\left(\mathrm{Ca}^{2+}, \mathrm{Mg}^{2+}\right.$ or $\left.\mathrm{Fe}^{2+}\right)$ and is blocked by inhibitors of respiration, the implication being that darkening is an energy-requiring process. This last observation is in agreement with the results reported by Ensign (1976) that the energy for this stage was entirely derived from endogenous metabolism in Streptomyces viridochromogenes. Little is known about the role of divalent cations in the transition from phase bright to phase dark, but $\mathrm{Ca}^{2+}$ was the only component absolutely required for the loss of refractility of spores of $S$. viridochromogenes (Hirsch \& Ensign, 1976b), while for germination of Streptomyces griseus it was $\mathrm{Fe}^{2+}$ (Ensign, 1976). Macromolecular synthesis is not necessary and consequently darkening occurs in the presence of antibiotics that inhibit it. In S. viridochromogenes, Hirsch \& Ensign (1975) found that this transition takes place in the absence of protein synthesis, depending on an exogenous substrate, and is not inhibited by chloramphenicol. Therefore, darkening is basically a non-degradative process (dry weight remains constant during the darkening stage) that requires a divalent metal ion and is inhibited by agents that block ATP formation. The difference between this stage and that which is called initiation of germination of bacterial endospores, a characteristically degradative process with a loss of up to $30 \%$ of endospore dry weight (Powell \& Strange, 1953), must be emphasized. Germination of fungal spores does not include the marked degradative changes characterizing bacterial endospore germination (Attwell \& Cross, 1973).

The next stage, swelling, is dependent exclusively upon an external supply of an assimilable carbon source such as glucose. DNA synthesis is not required and swelling occurs in the presence of mitomycin $C$; in the presence of streptomycin or rifampicin, swelling is severely retarded (Table 3). Dry weight remains practically unchanged from the start of incubation until after about $120 \mathrm{~min}$, the time corresponding to the maximum number of swollen spores. This seems to indicate that swelling is mainly due to rehydration of the cytoplasm. The fact that swelling requires a carbon source may indicate that water uptake is an active process and does not occur by osmosis alone. Swollen spores have the highest respiratory quotient, cytochrome oxidase and catalase activities. Kalakoutskii \& Pouzharitskaja (1973) also found in germinating spores of Actinomyces streptomycini (Actinomyces is synonymous with Streptomyces in Russian literature) that the maximum respiratory rate is reached just before the emergence of germ tubes. The ultrastructure of the spore at this stage shows remarkable changes with respect to the dormant spores. In the cytoplasm there are many ribosomes corresponding to a cell with high biosynthetic activity. The nuclear material presents an irregular shape without defined boundaries, an aspect that corresponds to the DNA in active transcription (Ryter \& Chang, 1975). Changes in the spore wall were also observed and the presence of layers of different electron density in the wall of the swollen spore was clearly visible.

Germ tube emergence requires both carbon and nitrogen sources. The effects of amino acids on germination vary among species of Streptomyces. Hirsch \& Ensign (1976a) obtained the best results in $S$. viridochromogenes by adding pairs of amino acids (L-alanine and L-glutamate or L-tyrosine and L-glutamate). Shigaeva \& Ramankulov (1971) found that all of five species of Streptomyces were inhibited by L-glutamate and stimulated by L-valine. Spores of $S$. antibioticus germinated on a defined medium consisting of mineral salts, glucose and $\left(\mathrm{NH}_{4}\right)_{2} \mathrm{SO}_{4} ; \mathrm{L}$-valine had no effect on germination, as Hirsch \& Ensign (1975) also found in $S$. viridochromogenes, but L-glutamate had an inhibitory effect. As a 
carbon and nitrogen source, L-alanine was the only one of the amino acids tested which allowed germination of $S$. antibioticus spores. DNA synthesis started at this stage, after about 150 to $160 \mathrm{~min}$ of incubation, and as Setlow \& Kornberg (1970) also found in bacterial endospores, the initiation of DNA synthesis signals the beginning of outgrowth. Similar results were also reported in Azotobacter cysts (Loperfido \& Sadoff, 1973). Dry weight increased rapidly and, as expected, germ tube emergence was blocked by antibiotics that inhibited macromolecular synthesis. The ultrastructure of the spores at this stage showed that the inner spore wall gives rise to the germ tube wall by growing out through the remains of the outer wall. Similar observations were made by Glauert \& Hopwood (1961) in S. violaceoruber, Bradley \& Ritzi (1968) in S. venezuelae, Dorokhova et al. (1969) in $S$. streptomycini and Sharples \& Williams (1976) in S. osteogriseus. The germination process in S. antibioticus has no stage equivalent to that of heat activation, characteristic of bacterial endospores. Heat treatment of spores for $10 \mathrm{~min}$ at $55^{\circ} \mathrm{C}$ before incubation, as described by Hirsch \& Ensign $(1976 b)$, had no effect on the germination rate. A similar lack of activation was also reported for Azotobacter cysts (Loperfido \& Sadoff, 1973).

Macromolecular synthesis during germination of $S$. antibioticus spores occurs in the following sequence: RNA, protein and DNA. A similar sequence takes place during germination of Bacillus endospores (Balassa \& Contesse, 1965; Kobayashi et al., 1965) and Azotobacter cysts (Loperfido \& Sadoff, 1973). Both RNA and protein synthesis began very soon and therefore spores probably contained the necessary enzymes and pools of nucleic acid precursors and amino acids.

Inhibitors of macromolecular synthesis (streptomycin, rifampicin and mitomycin C) completely inhibited incorporation of labelled precursors when added at zero time. During the germination process, rifampicin and streptomycin inhibited all macromolecular synthesis irrespective of the time of addition. Mitomycin $\mathrm{C}$, when added before the beginning of RNA synthesis, also inhibited all macromolecular synthesis, but once $\left[{ }^{3} \mathrm{H}\right]$ uracil uptake had been initiated, it blocked only DNA synthesis.

The authors wish to thank Dr T. Cross, Postgraduate School of Studies in Biological Sciences, University of Bradford, for helpful discussions and critical reading of the manuscript. J.E.S. was the recipient of a predoctoral fellowship from the Ministry of Education of Spain.

\section{REFERENCES}

Attwell, R. W. \& Cross, T. (1973). Germination of actinomycete spores. In The Actinomycetales: Characteristics and Practical Importance, pp. 197207. Edited by G. Sykes and F. A. Skinner. London and New York: Academic Press.

Balassa, G. \& Contesse, A. (1965). Synthèses macromoleculaires au cours de la germination des spores de Bacillus subtilis. I. Cinétique. Annales de l'Institut Pasteur 109, 683-705.

Bradley, S. G. \& Ritzi, D. (1968). Composition and ultrastructure of Streptomyces venezuelae. Journal of Bacteriology 95, 2358-2364.

Burton, K. (1956). Study of the condition and mechanism of the diphenylamine reaction for the colorimetric estimation of DNA. Biochemical Journal 62, 315-323.

Cole, J. A. \& Rittenberg, S. C. (1971). A comparison of respiratory processes in Spirillum volutans, Spirillum itersonii and Spirillum serpens. Journal of General Microbiology 69, 375383.

Cross, T. \& Attwell, R. W. (1975). Actinomycete spores. In Spores VI, pp. 3-14. Edited by P.
Gerhardt, R. N. Costilow and H. L. Sadoff. Washington, D.C.: American Society for Microbiology.

Dorokhova, L. A., Agre, N. S., Kalakoutskit, L. V. \& Krassilnikov, N. A. (1969). Comparative study on spore structure and germination in Actinomyces streptomycini and Micromonospora vulgaris. 7th U.S.S.R. Conference on Electron Microscopy, Abstract Communication, Section IV, p. 172.

ENSIGN, J. C. (1976). Properties and germination of Streptomyces spores and a suggestion for function of antibiotics. In Microbiology-1976, pp. 531-533. Edited by D. Schlessinger. Washington, D.C.: American Society for Microbiology.

Glauert, A. M. \& Hopwood, D. A. (1961). The fine structure of Streptomyces violaceoruber (Streptomyces coelicolor). III. The walls of the mycelium and spores. Journal of Biophysical and Biochemical Cytology 10, 505-516.

Gomori, G. (1955). Preparation of buffers for use in enzyme studies. Methods in Enzymology 1, 138146.

MIC 105 
HaRdisson, C. \& Manzanal, M. B. (1976). Ultrastructural studies of sporulation in Streptomyces. Journal of Bacteriology 127, 1443-1454.

Hirsch, C. F. \& Ensign, J. C. (1975). Germination of Streptomyces viridochromogenes spores. In Spores VI, pp. 28-35. Edited by P. Gerhardt, R. N. Costilow and H. L. Sadoff. Washington, D.C.: American Society for Microbiology.

HirsCh, C. F. \& ENSIGN, J. C. (1976a). Nutritionally defined conditions for germination of Streptomyces viridochromogenes spores. Journal of Bacteriology 126, 13-23.

Hirsch, C. F. \& Ensign, J. C. (1976b). Heat activation of Streptomyces viridochromogenes spores. Journal of Bacteriology 126, 24-30.

Jurtshuk, P., Marcucci, O. M. \& McQuitTy, D. N. (1975). Tetramethyl-p-phenylenediamine oxidase reaction in Azotobacter vinelandii. Applied Microbiology 30, 959-963.

Kalakoutskit, L. V. \& Agre, N. S. (1976). Comparative aspects of development and differentiation in Actinomycetes. Bacteriological Reviews 40, 469-524.

Kalakoutskit, L. V. \& Pouzharitskaja, L. M. (1973). The Streptomyces spore: its distinct features and germinal behaviour. In The Actinomycetales: Characteristics and Practical Importance, pp. 155-178. Edited by G. Sykes and F. A. Skinner. London and New York: Academic Press.

Kobayashi, Y., Steinberg, W., Higa, A., HalVORSON, H. O. \& LeVinthal, C. (1965). Sequential synthesis of macromolecules during outgrowth of bacterial spores. In Spores III, pp. 200-212. Edited by L. L. Campbell and H. O. Halvorson. Ann Arbor, Michigan: American Society for Microbiology.

LAMMI, C. J. \& VARY, J. C. (1972). Deoxyribo- nucleic acid synthesis during outgrowth of Bacillus megaterium QM B1551 spores. In Spores $V$, pp. 277-282. Edited by H. O. Halvorson, R. Hanson and L. L. Campbell. Washington, D.C.: American Society for Microbiology.

LOPERFIDO, B. \& SADOFF, H. L. (1973). Germination of Azotobacter vinelandii cysts: sequence of macromolecular synthesis and nitrogen fixation. Journal of Bacteriology 113, 841-846.

Lowry, O. H., Rosebrough, N. J., FarR, A. L. \& RANDALL, R. J. (1951), Protein measurement with the Folin phenol reagent. Journal of Biological Chemistry 193, 265-275.

Powell, J. F. \& Strange, R. E. (1953). Biochemical changes occurring during the germination of bacterial spores. Biochemical Journal 54, 205-209.

RoRTH, M. \& JENSEN, P. K. (1967). Determination of catalase activity by means of the Clark oxygen electrode. Biochimica et biophysica acta 139, 171-173.

RYTER, A. \& CHANG, A. (1975). Localization of transcribing genes in the bacterial cell by means of high resolution autoradiography. Journal of Molecular Biology 98, 797-810.

SCHNEIDER, W. C. (1957). Determination of nucleic acids in tissues by pentose analysis. Methods in Enzymology 3, 680-689.

Setlow, P. \& Kornberg, A. (1970). Biochemical studies of bacterial sporulation and germination. XXIII. Nucleotide metabolism during spore germination. Journal of Biological Chemistry 245, 3645-3652.

Sharples, G. P. \& Williams, S. T. (1976). Fine structure of spore germination in Actinomycetes. Journal of General Microbiology 96, 323-332.

Shigaeva, M. K. \& Ramankulov, T. (1971). Effect of amino acids on spore germination in Actinomycetes. Mikrobiologiya 40, 1021-1023. 